\section{A NEW WOMAN'S VENTURE: LINKING A LITTLE MAGAZINE TO THE SUFFRAGE ATELIER} Ryerson University Toronto, Ontario, Canada
Emma Fraschetti, 201

Centre for Digital Humanities

\section{The Venture: An Annual of Art and Literature}

Art and Literature, a little magapublished in 1903 by John Baillie in London and in 1905 by The
arden Press in Leamington. The magazine made its debut at a pervade literature and public discourse. Although its co-editors
were both men, Maugham was a supporter of women's suffrase and Housman was notable for his activism, acting as a central igure in the Men's League for Women's Suffrage established

The Venture presented Maugham and Housman with the opportunity to use their authority as editors to participate in
proader social and political affairs. Expressed throughout the broader social and political a affirs. Expressed throughout the Contents examine the varying experiences of modern women in Victorian societty and as a whole, the magazine works to
piomote and cellebrate the achievements of New Women. The curation of feminist work in The venture is unlikely a coinci-
dence, and it would be a mistake to dismiss it as such. This edited The Venture with a primarily feminist agenda in order to promote women's suffrage, and inspire curiosity, individuality,

\section{The Venture and The New Woman}

Literary Contents

The examination of modern femininity and the New Woman is continual throughout The
Venture. For example, "The Gem and Its Setting" a play by Violet Hunt exposes the prejudice What modern women are subjecteded to tor opposing g the traditional standards of behaviour for
that Women engaged in romantic relationships. Poor Little Mrs. Villers" by Netta Syrett is a short
story which conveys victorian society's contrasting opinions on divorce for women. "Marriages tic experiences. In these works,

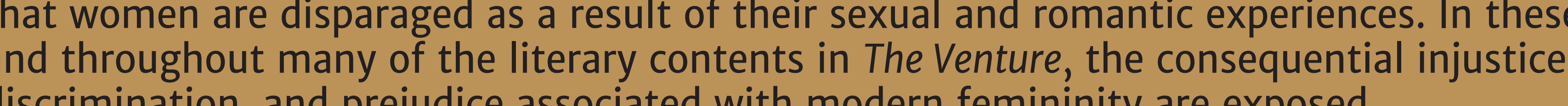
discrimination, and prejudice associated with modern femininity are exposed.

The contributions to The Venture also depict the positive experiences of modern women
well. "The Last Journey" by Netta syrett is a short-story featured in volume II about an Englishwoman named Cecilia who boards an omnibus alone near Piccadilly Circus and rides late
into the night through the city of London. She fantasizes about her environment; perceiving the

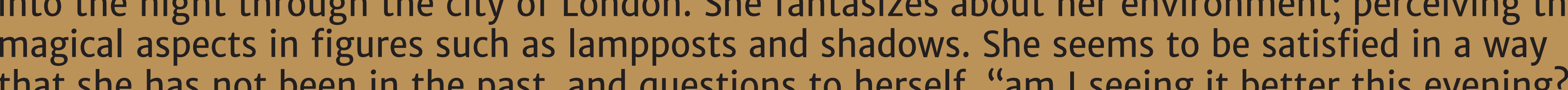
(Syrett 42 ) It is evident that cecilia is incredibly excited to be able to exercise her curiosity, magination, and independence. By exemplifying the experiences of a woman who has a
happiness by rightully indulging in her own agency and desire, syrett promotes the New

\section{Art Contents}

The Venture further celebrates the modern femininity by featuring artistic reproductions and analyses of New Women, mostly contributed by by Ann Macbeth" "Autumn Leaves" by Pam ayse

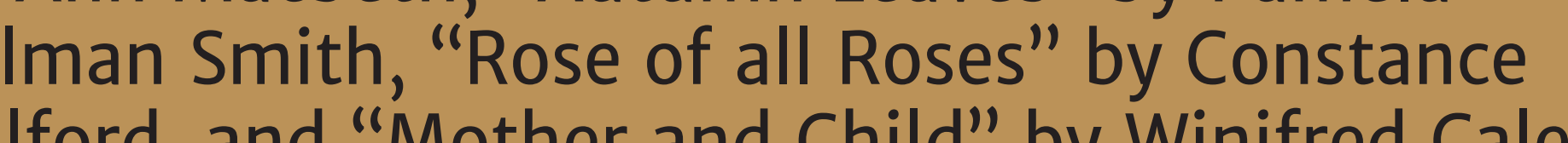
. ditionce by depicting women confidently and "The Death of Pan," engraved by Louise Glazier, an

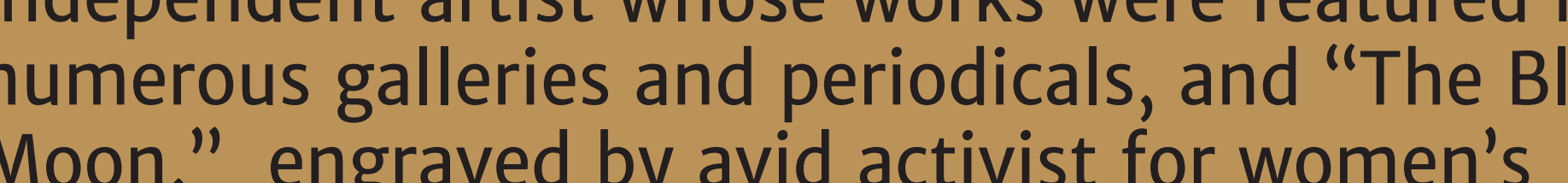
Inportant because hey promote the achievements and values of female artists, they are also
important because they mark the beginning of a important because they mark the eegining of
creative-based approach to disseminating the ideologies of modern feminism.

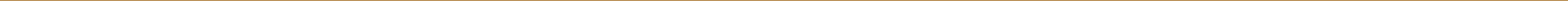
Arcen ress in Leamingtont. The magaf femininity began to
time when new sociopolitical ideas of feming promote and celebrate the achievements of New Women.

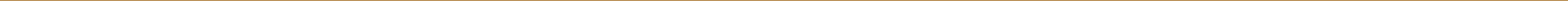
suffrage and co-founder of the suffrage Atelier,

\section{The Beginnings of Women's Suffrage}

To understand the significance of The Venture to the women's movement in Victorian
England, the state of suffrage during this time must first be considered. Women's suffrage ecame a prominent social and political issue in the mid 19th century. The campaign for

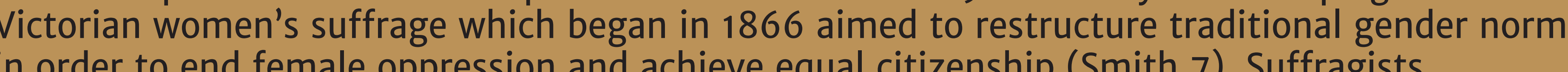
protested for the elimination of restrictions on women's education employ and legal authority ( $S$ mith 3). In addition to active protest, the campaign encouraged feminin solidarity and pride by promoting the achievements of modern women.

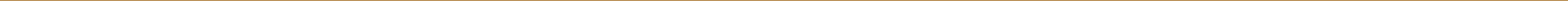
A notable moment in the women's movement
was the publication of Sarah Grand's sssay "The New Aspect of the Woman Question" in 1894,
which revised the definition of the "New Woman." Grand asserted that the New Woman was selfthrough exercising her agencyi (Led ger and Luckhurst 80). Most importantly, the New Woman had enlightened because she was able to acknowlWoman's-Sphere" and seek fulfilment beyond it
Wortive (Ledger and Luckhursts 89). In redefining the New perspective on conventional gender roles.
ponts
WhataMan may have been, \& yet not lose the Vote

The Suffrage Atelier

The Suffrage Atelier, which regarded itself as an arts and crafts society working for the (Tickner 21). With the objective of forvarding the women's movement by disseminating art We Atelier produced advertisements, banners, postcards, and decorations which promoted exhibited in galleries, published in the press, and sold for suffragist rallies and processions

Unlike the members of the Artist's
Suffrage League (1907-1018)

Suffrage League (1907-1918) who were
professional artists, the Atelier's members

were comprised of both professionals and ioned an educational centre by providing and develop their technique with peers of women were able to form relationships with those who shared their passions and values, through the expression of their craft In and of itself, the Atelier was integral in the formation of wh
suffragists.
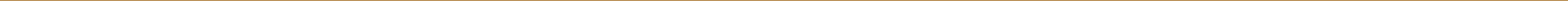

When comparing the art in The Venture to the art created and disseminated by the Suffrage Atelier's works were produced as block prints such as wood-curts. They varied in size and were

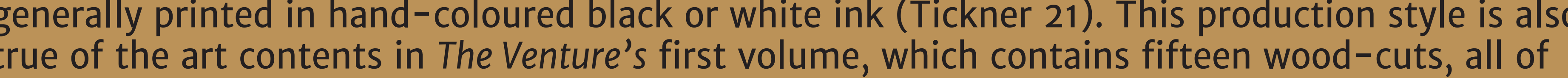
which were printed in black ink with the exception of the frontispiece. A wood-cut from this

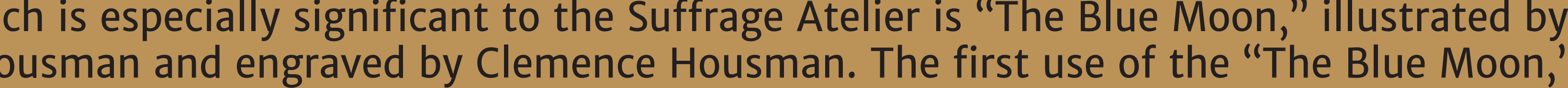
titile-page was in The Venture in 1903. Although the feature of "The Blue Moon" in the magazin

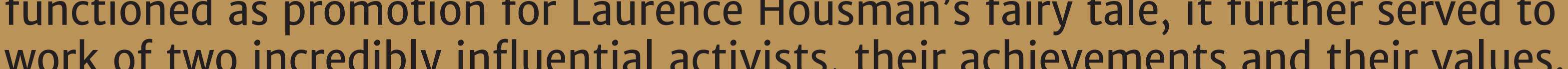

Ties to the Atelier are also evident in the contributors to The Venture. A number of New the women's movement. Notably Pamela colman Smith, whose illustration "Au untumn Leaves" featured in volume II was a member of the Suffrage Atelier. In addition to her work as an inde(1911), and designed multiple posters for the Atelier such as "A Bird in the Hand" (Tickner 34). Smith also edited and published her
own magazine, The Greeen Sheaf (1903-1904) for which advertisements were placed in the second own magazine, The Gre.
volume of The venture.

Most importantly, political ambitions and means of activism are shared by The Venture and

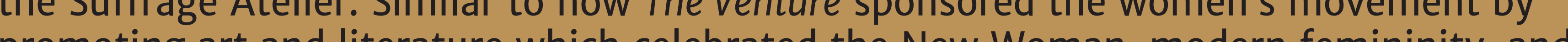

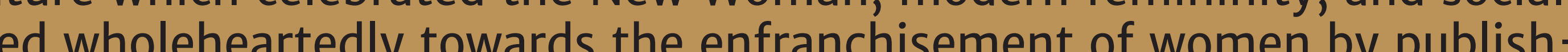
ing feminist art. Considering these similaritities between The Venture and the Suffrage Atelier, and

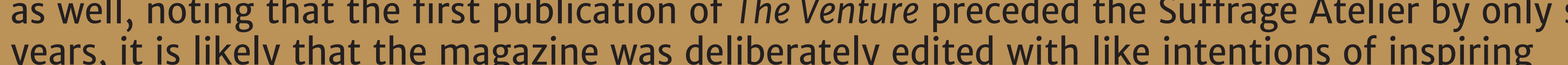
female activism to those that were later involved in the establishment of the Atelier in production of The Venture influenced the beginning of the Suffrage Atelier's formation.

\section{Conclusion}

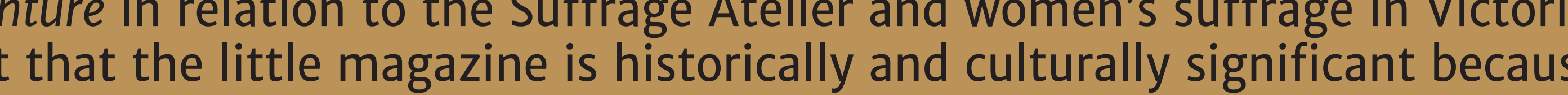
it lends insight into the direction of women's activism and artistic involvement in the late 19 th and early 20 th century. As Housman and Maugham sought social justice, equal rights, and
progression of the women's movement, it is clear that the contributions to The Venture, especially those which promote ideologies of the New Woman and modern femininity, were not
arbitrarily curated. The magazine was deliberately published with a feminist agenda in order to engage the public in discourse about women's suffrage. Moreover, The Venture is important

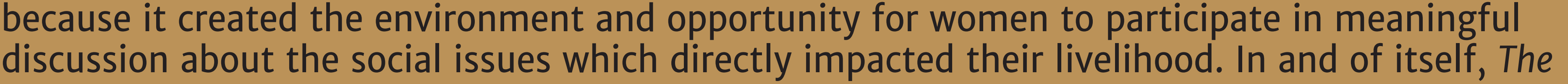
Siscussion about the social issues which directly impacted theil live
Venture was a product of activism which also intended to inspired it.
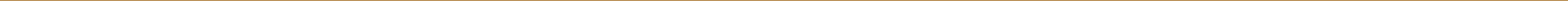